\title{
PEMBELAJARAN FIQH MU'ĀMALĀT BERORIENTASI LITERASI FINANSIAL
}

\author{
Adib Rifqi Setiawan*, \\ Mita Puspaningrum, Khoirul Umam \\ Pondok Pesantren Ath-Thullab Kudus dan \\ Universitas Stikubank, Semarang, Indonesia
}

*E-mail:alobatni@@gmail.com

\begin{abstract}
Financial literacy is the knowledge and understanding of financial concepts and risks, and the skills, motivation and confidence to apply such knowledge and understanding in order to make effective decisions across a range of financial contexts, to improve the financial well-being of individuals and society, and to enable participation in economic life. This research goals are to gain the design for a learning program that is aligning fiqh mu'amalat and financial literacy. We used research and development approach with four-D model that is reduced into three stages: define, design, and develop. It was gained a syllabus that is completed by lesson plan, student worksheets, and assessment instrument as well, that is validated by experts and practitioners and reliability counted based on test. The final test of these educational ideas are in learning implementation. The implementation of this program is not carreid out yet.
\end{abstract}

Keywords: financial literacy, fiqh mu'āmalät, learning program

\begin{abstract}
Abstrak. Literasi finansial adalah pengetahuan dan pemahaman tentang konsep-konsep keuangan dan risiko, serta keterampilan, motivasi dan kepercayaan diri untuk menerapkan pengetahuan dan pemahaman tersebut untuk membuat keputusan yang efektif di berbagai konteks keuangan, guna meningkatkan kesejabteraan keuangan individu dan masyarakat, dan untuk memungkinkan partisipasi dalam kehidupan ekonomi. Riset ini bertujuan untuk mendapatkan desain untuk program pembelajaran yang menyelaraskan fiqh mu'ämalät dan literasi finansial. Kami menggunakan pendekatan research and development model four-D yang direduksi menjadi tiga tahap: mendefinisikan, merancang, dan mengembangkan. Diperoleh hasil berupa silabus yang dilengkapi oleh rencana pembelajaran, lembar kerja siswa, dan instrumen penilaian, yang divalidasi oleh para pakar dan praktisi serta keandalan dibitung berdasarkan uji coba. Tes akbir dari setiap gagasan pendidikan ini dalam implementasi pembelajaran. Implementasi program ini belum dilakukan.
\end{abstract}

Kata Kunci: fiqh mu'ämalät, literasi finansial, program pembelajaran 


\section{PENDAHULUAN}

Kesadaran pelajar tingkat menengah saat ini terhadap masalah finansial dapat dikatakan rendah. Temuan ini kami peroleh sebagai pengamat terlibat selama 40 hari terhadap keseharian santri Pondok Pesantren Ath-Thullab Kudus. Pondok pesantren tersebut menampung pelajar tingkat menengah dengan kisaran usia 11-19 tahun yang kebutuhan finansial sepenuhnya ditanggung oleh wali. Temuan tersebut mengungkap bahwa sebagian besar santri tidak menyadari dampak rincian pengeluaran harian terhadap keadaan finansial bulanan serta tidak peduli dengan besaran biaya pendidikan di pondok pesantren yang ditanggung oleh setiap wali. Kedua fakta tersebut ditambah data lain berupa kecenderungan perilaku sebagian kecil santri yang menambah kerepotan sekaligus pengeluaran wali, hasil pengamatan khusus terhadap kebijakan merit dalam pencairan titipan uang saku, serta alasan yang mendasari keputusan dalam bertransaksi.

Anggapan bahwa santri tidak menyadari dampak rincian pengeluaran harian terhadap finansial bulanan ditunjukkan oleh beberapa hal. Misalnya ketika akan membeli barang non-rutin dengan harga setara pengeluaran jajan selama sepekan. Dampaknya wali harus kembali mengeluarkan uang saku sebelum waktu yang direncanakan. Pengurus pondok pesantren yang terdiri dari santri relatif paling tua dapat dikatakan sama saja. Kesamaan muncul karena pengurus tidak pernah membuat perencanaan pengeluaran tahunan yang rapi dan rinci seperti diminta oleh salah satu pembina pondok pesantren.

Ketidakpedulian kepada besaran biaya pendidikan di pondok pesantren yang dikeluarkan oleh setiap wali tampak dengan pengabaian terhadap informasi rincian penggunaan biaya pendidikan. Padahal informasi tersebut bersifat terbuka. Menarik untuk diperhatikan bahwa santri yang mengabaikan informasi tersebut, ketika ditanya terkait pembayaran bulanan, segera menghubungi wali. Dari sini tampak bahwa santri peduli kepada kewajiban sekaligus acuh terhadap hak. Dampak ekstrim perilaku seperti ini antara lain tampak kentara ketika rapat evaluasi makanan: sebagian santri menyampaikan permintaan menu makanan yang melebihi anggaran serta sebagian lain menerima seutuhnya penuh kerelaan.

Beberapa perilaku sebagian kecil santri yang menambah kerepotan sekaligus pengeluaran wali juga menunjukkan bahwa tingkat kesadaran terhadap masalah finansial terbilang rendah. Beberapa santri tampak tak memperhitungkan besaran biaya tambahan yang harus dikeluarkan oleh wali ketika meminta ditelepon, dikunjungi, atau dijemput pulang di luar jadwal. Di luar masalah finansial secara langsung, tidak terdapat pula kesadaran dari beberapa santri bahwa perilaku tersebut berdampak kepada keseharian wali, mulai merusak fokus ketika sedang bekerja, menambah lelah yang tak perlu saat akan kembali bekerja, sampai mengurangi keefektifan istirahat karena menimbulkan kecemasan.

Pengamatan lain yang dilakukan secara khusus kepada beberapa santri yang menitipkan uang saku kepada pembina juga menguatkan hasil pengamatan umum. Kalau terkait pembayaran bulanan beberapa santri tampak acuh terhadap hak, untuk urusan jajan harian mereka kerap melupakan kewajiban sekaligus menuntut hakuntuk keperluan ini uang saku dianggap hak. Temuan ini tampak dari tanggapan santri tersebut terhadap penerapan merit untuk pencairan titipan uang saku, yang membuat tidak dapat dijalankan secara optimal.

Terkait alasan yang mendasari keputusan dalam bertransaksi kami 
peroleh dari beberapa santri yang menggunakan kartu anjungan tunai mandiri (ATM). Hampir semua santri mengatakan bahwa kartu ATM hanya berguna untuk menarik tunai tanpa harus ke bank. Padahal beberapa bank seperti Bank Negara Indonesia (BNI) sudah membuka layanan setor menggunakan kartu ATM. Lebih lanjut, mereka pun tidak tahu tentang kontrak ('aqd) terkait perbankan dari sisi fiqh mu'āmalāt. Selain itu, walau semua santri sudah mengerti bahwa ribā adalah larangan umum dalam semua transaksi, mereka tidak dapat menjelaskan posisi bunga bank (bank interest) dalam ruang lingkup ribā.

Di sisi lain, sebagai pemandu pembelajaran sorogan kitab kuning, kami juga mengalami kebingungan terkait kelanjutan pembelajaran tersebut. Pembelajaran sorogan dipakai untuk melatih keterampilan santri dalam mengomunikasikan kajian terhadap teks kitab kuning. Kitab kuning yang dipilih adalah Taqrīb untuk santri MTs (Madrasah Tsanawiyyah) dan Fath alQorīb untuk santri MA (Madrasah 'Aliyyah). Pilihan kitab kuning tersebut diambil karena matn Taqrīb yang disyarḥ-i Fath al-Qorīb adalah textbook klasik paling ringkas yang memuat pembahasan fiqh maẓhab Syāfi'̄ secara utuh. Kebingungan mulai muncul ketika sebagian besar santri MTs hampir selesai menyajikan topik ibādāt. Letak kebingunan ialah antara melanjutkan ke bagian mu'āmalāt yang diurai dalam Taqrīb atau mengalihkan ke bagian ibādāt dari Fatḥ al-Qorīb. Alhasil keputusan memperhatikan fiqih mu'āmalāt memberi jawaban dalam bentuk solusi untuk mengatasi kebingungan tersebut.

Informasi tersebut melatarbelakangi harapan kami untuk mewujudkan pembelajaran fiqh mu'āmalāt sebagai upaya membimbing pelajar tingkat menengah mencapai literasi finansial.
Literasi finansial yang disebut di sini bermakna kemampuan menafsirkan informasi finansial sebagai bahan membuat keputusan agar siap menerima dampak yang diperoleh. Misalnya memahami dampak pembelian barang non-rutin terhadap kondisi uang saku bulanan. Sebagai pelajar pondok pesantren, mestinya keputusan finansial juga didasari oleh fiqh. Contohnya ketika ingin membuka rekening bank.

Berdasarkan sebaran informasi yang disampaikan, kami memandang bahwa fiqh mu'āmalāt dan literasi finansial dapat dipadukan sebagai program pembelajaran. Program tersebut dapat diwujudkan dengan cara mengkaji indikator yang dibekalkan kepada pelajar, bukan sekadar membiasakan mengerjakan soal literasi finansial yang diperkaya topik fiqh mu'āmalāt.

Riset ini diarahkan untuk memperoleh rancangan program pembelajaran fiqh mu'āmalāt berorientasi literasi finansial tingkat pendidikan menengah. Secara khusus, kami bermaksud menyusun program yang dapat digunakan dalam pembelajaran di pondok pesantren tanpa perlu mengubah struktur kurikulum yang berlaku. Tingkat pendidikan menengah dipilih karena pada rentang tersebut sebagian besar pelajar dapat dikatakan mandiri ketika terlibat transaksi finansial, meski masih bergantung kepada wali dalam memperoleh pemasukan. Pondok pesantren dipilih karena lembaga otentik Indonesia ini memiliki tujuan untuk memberi keterampilan hidup melalui pendidikan kajian keislaman (Octavia, 2014, 1; Madjid, 1997: 17). Dengan demikian, rumusan masalah yang menjadi fokus dalam riset ini ialah, "Bagaimana susunan program pembelajaran fiqh mu'āmalāt berorientasi literasi finansial?." 


\section{METODE PENELITIAN}

Data yang dibutuhkan dalam penelitian ini berupa kajian pustaka tentang karakteristik dan peta fiqh mu'ämalät maupun kerangka kerja literasi finansial serta survei terhadap rancangan dan temuan dari uji coba program yang disusun. Berdasarkan tujuan penelitian dan kebutuhan data, dapat dipakai pendekatan research and development desain four-d model berupa define, design, develop, dan disseminate (Thiagarajan, dkk., 1974: $5)$.

Desain four-d model dipilih karena kami perlu beberapa tahap yang masingmasing memerlukan cara pengumpulan dan pengolahan data yang tidak selalu sama. Namun, karena keterbatasan tenaga, desain direduksi menjadi 3 tahap berupa define, design, dan develop. Tahap define dilakukan untuk mengkaji pustaka terkait karakteristik dan peta fiqh mu'amalah maupun kerangka kerja literasi finansial. Luaran kajian tersebut berupa kaitan antara fiqh mu'ämalah dan literasi finansial sebagai acuan dalam menyusun instrumen penilaian pembelajaran dan lembar kerja siswa di tahap design. Susunan yang diperoleh dipakai sebagai bahan merancang program pembelajaran dalam bentuk silabus di tahap develop. Tahap develop juga dipakai untuk menganalisis keabsahan dan keandalan perangkat pembelajaran melalui ujicoba terbatas.

Tabel 1. Desain Riset

\begin{tabular}{ccccc}
\hline Tahap & $\begin{array}{c}\text { Pengumpulan } \\
\text { Data }\end{array}$ & $\begin{array}{c}\text { Pengolahan } \\
\text { Data }\end{array}$ & Partisipan Riset & Instrumen Riset \\
\hline Define & Kajian pustaka & $\begin{array}{c}\text { Analisis } \\
\text { deskriptif }\end{array}$ & Penulis & - \\
\cline { 1 - 3 } Design & Tabel analisis & Penyekoran \\
hevelop & Judgement expert & $\begin{array}{c}\text { Pakar fiqh mu'ämalät, } \\
\text { pendidikan menengah, } \\
\text { bidang finansial, dan } \\
\text { bahasa. }\end{array}$ & Lembar survei validasi \\
\cline { 2 - 3 } & Internal consistency & Koefisien alfa & $\begin{array}{c}\text { Pelajar pendidikan tingkat } \\
\text { menengah sebanyak } 50 \\
\text { orang }\end{array}$ & $\begin{array}{c}\text { Lembar pengamatan } \\
\text { pelaksanaan } \\
\text { pembelajaran, lembar } \\
\text { kerja siswa, \& } \\
\text { instrumen penilaian }\end{array}$ \\
\hline
\end{tabular}

\section{HASIL PENELITIAN DAN PEMBAHASAN}

Mahmada (2001) menyampaikan bahwa fiqh adalah kumpulan hasil ijtihād ulamā' klasik terhadap al-Qur'ān dan al-Hadīts sebagai dasar keseharian umat Islam dalam setiap konteks kehidupan, mulai personal seperti sholāt, lokal seperti zakāt, sampai global seperti politik. Sementara Umar (2014) menyebut bahwa fiqh adalah penafsiran kultural terhadap sumber syarīāt yang dikembangkan oleh ulamā' sejak abad kedelapan. Kedua ungkapan tersebut selaras dengan definisi figh yang dituturkan oleh beberapa ulamā' (alBantānī, 2008: 6; al-Ghozī, 2005: 22; alMalībārī, 2005: 34; al-Dimyāṭ̣̂, 1997: 21; al-Ḥuṣni, 1994: 7; al-Zuḥaylī, 1989: 29). Dapat dikatakan bahwa figh adalah dugaan kuat terhadap sumber syarīât sebagai bahan panduan praktis keseharian umat Islam yang berlaku untuk semua konteks mulai personal, lokal, nasional, sampai global. 
Pembahasan utuh fiqh secara umum biasa dimulai dari topik 'ibādāt, lalu mu'āmalāt, kemudian dilanjutkan ke topik lain seperti munākaḥāt dan jināyāt (al-Bantānī, 2008; al-Ghozī, 2005; alMalībārī, 2005; al-Dimyāṭ̂i, 1997; alḤuṣnī, 1994; al-Zuḥaylī, 1989). Urutan pembahasan tersebut disusun berdasarkan nilai penting setiap topik berdasarkan tinjauan syarī’āt serta tingkat keluasan konteks berlaku. Pembahasan paling awal berupa praktik ritual, dengan urutan sesuai dengan lima rukūn Islām (al-Dimyātīi, 1997: 1024). Selanjutnya karena kebutuhan manusia terhadap transaksi ekonomi adalah hal yang sangat penting, pembahasan topik mu'āmalāt diletakkan tepat setelah 'ibādāt (alDimyāțī, 1997: 734).

Dilihat dari sisi urutan pembahasan, tampak bahwa fiqh secara serius sangat memperhatikan masalah finansial. Keseriusan tersebut ditunjukkan dengan peletakan transaksi finansial tepat setelah pembahasan praktik ritual. Perhatian fiqh tersebut diwujudkan dalam bentuk memberi panduan operasional praktik transaksi finansial, antara lain berupa prinsip dasar, unsur hukm, serta ketentuan umum setiap jenis transaksi finansial. Transaksi yang dimaksud termasuk-sekaligus bukan hanyaragam penjualan, kemitraan, peminjaman, maupun penyewaan.

Di sisi lain, OECD (Organisation for Economic Co-operation and Development) (2005) selaku organisasi multilateral yang berupaya meningkatkan kualitas manusia secara global mulai memperhatikan masalah pendidikan finansial sejak 2005 silam. Secara khusus disarankan bahwa pendidikan finansial harus sedini mungkin dimulai di sekolah yang merupakan tahap awal kehidupan pelajar (OECD, 2005: 5). Alasan utama yang mendasari saran tersebut ialah nilai penting berfokus kepada generasi muda untuk membekali keterampilan yang penting sebelum terlibat aktif dalam transaksi finansial serta relatif lebih efisien untuk melakukan pendidikan finansial di sekolah ketimbang melakukan tindakan perbaikan untuk orang yang berusia tua.

Saran OECD (2005) tersebut kemudian dipertimbangkan sebagai bahan mengembangkan kerangka kerja literasi dari PISA (Programme for International Students Assessment) (OECD, 2019: 119). PISA adalah program internasional OECD untuk menilai performa akademik pelajar berusia 15 tahun yang bertujuan untuk memberi bahan dalam meningkatkan pendidikan negara yang terlibat (OECD, 2019: 11). Penilaian PISA berfokus terhadap kemampuan pelajar untuk menggunakan pengalaman terlibat pembelajaran ke dalam keseharian (OECD, 2019: 128). Fokus ini membedakan penilaian PISA dengan TIMSS (Trends in International Mathematics and Science Study), program dari IEA (International Association for the Evaluation of Educational Achievement), yang fokus terhadap penguasaan konten kurikuler tertentu.

Penilaian PISA tersebut biasanya dikenal lebih luas dengan istilah literasi. Literasi dalam kerangka kerja PISA dikelompokkan menjadi empat bagian: membaca, matematis, saintifik, dan finansial. Ketiga kelompok literasi pertama, yakni membaca, matematis, dan saintifik, masing-masing sudah pernah menjadi fokus utama penilaian pada tahun tertentu, yang diperbarui setiap 9 tahun (OECD, 2019: 11). Sementara kelompok terakhir yakni literasi finansial, baru masuk dalam penilaian sejak 2012 tanpa pernah menjadi fokus utama, malah sampai sekarang masih menjadi penilaian pilihan (OECD, 2019: 12).

Fakta tersebut membuat literasi finansial lebih sedikit diperhatikan di Indonesia, baik dari sisi kajian akademik maupun praktik pembelajaran, khususnya untuk pendidikan menengah 
maupun pondok pesantren. Namun, perhatian sedikit tidak membuat government Indonesia luput memberi perhatian. Bentuk perhatian tersebut ialah menetapkan kebijakan untuk meningkatkan literasi finansial melalui program Strategi Nasional Literasi Finansial pada 19 November 2013 (OJK, 2017: 2; OECD, 2015: 12; Setneg, 2013). Program ini dirilis sebagai upaya mewujudkan literasi finansial masyarakat Indonesia, sehingga dapat memanfaatkan produk dan layanan jasa finansial yang sesuai untuk mencapai kesejahteraan berkelanjutan.

Fiqh adalah dugaan kuat terhadap sumber syar'ät sebagai bahan panduan praktis keseharian umat Islam yang berlaku untuk semua konteks mulai personal, lokal, nasional, sampai global (Umar, 2014: 1; al-Bantānī, 2008: 6; alGhozī, 2005: 22; al-Malībārī, 2005: 34; Mahmada, 2001; al-Dimyāțī, 1997: 21; al-
Huuṣnī, 1994: 7; al-Zuḥaylī, 1989: 29). Berdasarkan arahnya, peta fiqh dapat diklasifikasi menjadi 2 kelompok besar: ibädāt dan mu'àmalāt. Arah pembahasan kelompok ibädàt ialah hubungan antara manusia dengan Allōh (hablun min Allōh), sementara mu'ämalāt adalah kelompok yang arahnya membahas hubungan antara manusia dengan selain Allōh (hablun min al-nas dan hablun min al-'alam). Namun, ketika textbook fiqh mengungkap kata mu'ämalàt secara mutlak, ruang lingkup pembahasan ialah mu'àmalāt mäliyyaat (transaksi finansial). Hal ini dapat ditemukan ketika kita mengamati textbook figh utuh, seperti al-Ghoyah wa al-Taqrï, Fath al-Mu'in, dan al-Figh al-Islami wa Adillatubu (al-Aṣfihāāni, 2019; al-Malībārī, 2005; al-Zuhaylī, 1989). Istilah mu'āmalät dalam riset ini ialah mu'amalàt mäliyyāt, sehingga tidak mencakup topik munākahạat dan jināyāt.

Tabel 2. Kitab Kuning Fiqh di Lingkungan Madrasah Tasywiquth Thullab Salafiyyah

\begin{tabular}{|c|c|c|c|}
\hline Kitab Kuning & $\begin{array}{c}\text { Kategori } \\
\text { Penyajian }\end{array}$ & $\begin{array}{c}\text { Pondok Pesantren Ath- } \\
\text { Thullab }\end{array}$ & $\begin{array}{c}\text { Madrasah Tasywiquth } \\
\text { Thullab Salafiyyah }\end{array}$ \\
\hline \multirow{2}{*}{ al-Ghōyah wa al-Taqrīb } & \multirow{2}{*}{ Matn } & Sorogan (MTs) & Pembelajaran Fiqh \\
\hline & & Musyāwaroh (MTs) & (VII, VIII, dan MPA) \\
\hline Qurrotu al'Ayn & Matn & - & Pembelajaran Fiqh (IX) \\
\hline \multirow{2}{*}{ Fath al-Qorì al-Mujīb } & \multirow{2}{*}{ Syarh } & Sorogan (MA) & \multirow{2}{*}{$\begin{array}{c}\text { Pembelajaran membaca kitab } \\
\text { kuning }(\mathrm{X}-\mathrm{XII})\end{array}$} \\
\hline & & Musyäwaroh (MA) & \\
\hline \multirow[b]{2}{*}{ Fath al-Mu'in } & \multirow[b]{2}{*}{ Syarh } & \multirow{2}{*}{$\begin{array}{c}\text { Bandongan } \\
\text { (semua santri) }\end{array}$} & Pembelajaran Fiqh (X - XII) \\
\hline & & & $\begin{array}{l}\text { Ujian membaca kitab kuning } \\
\text { (XII) }\end{array}$ \\
\hline
\end{tabular}

Pembelajaran aktual di Madrasah Tasywiquth Thullab Salafiyyah (TBS) Kudus, termasuk Pondok Pesantren Ath-Thullab, didasarkan secara langsung terhadap uraian kitab kuning. Karena itu, fiqh mu'amalah baru mulai dipelajari di tingkat menengah. Di tahap define ini, peta fiqh mu'amalah didasarkan secara langsung terhadap seluruh kitab kuning yang dipakai tersebut. Setiap kitab kuning memiliki perbedaan cakupan dan kedalaman ulasan terhadap ragam transaksi. Namun secara umum, dapat diperoleh kesamaan dalam tiga kategori berupa: prinsip dasar, unsur hukm, dan jenis transaksi. Prinsip dasar figh mu'amalah berupa transaksi harus: berdasarkan kesepakatan bersama antar pelaku yang diungkapkan secara sadar, transparan, dan memperhatikan aspek keadilan. Unsur hukem dalam transaksi mencakup: abliyyah (kapasitas hukm) berupa pelaku transaksi sudah pubertas dan waras; mäl (kekayaan) berupa sesuatu yang berguna dan bernilai, bukan berupa barang harōm (dilarang), serta rincian 
kepemilikan sudah diketahui antar pelaku transaksi; milkiyyah (kepemilikan) menyangkut jenis, metode, dan cakupan kepemilikan; serta 'aqd (kontrak) yang menjelaskan kerangka kerja hubungan hukm yang dibuat oleh pelaku transaksi dalam memanfaatkan kekayaan, seperti bai' (penjualan) dalam bentuk tatap muka atau jarak jauh, musyārokah (kemitraan) permanen maupun berjangka, serta ijäroh (penyewaan) benda atau jasa.

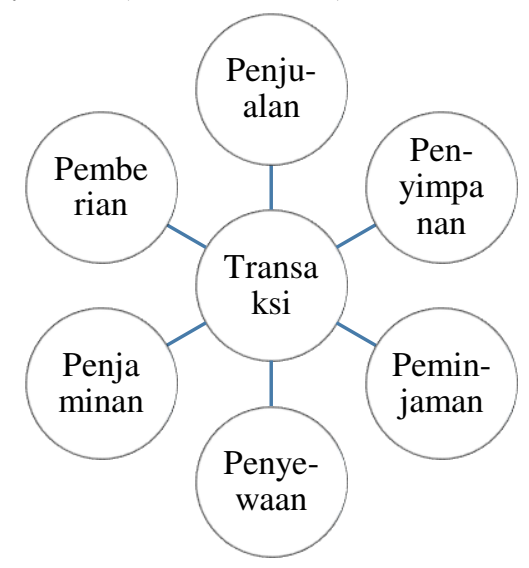

Gambar 1. Klasifikasi Transaksi Finansial Berdasarkan Pemindahan Hak Milik

Literasi finansial dalam kerangka kerja PISA dibagi ke dalam 3 domain: konten, proses, dan konteks (OECD, 2019: 119-164). Domain konten adalah bidang yang harus dimengerti ketika terlibat transaksi finansial. Domain konten mencakup: uang dan transaksi, perencanaan dan pengelolaan finansial, risiko dan imbalan, serta lanskap finansial. Domain proses adalah sisi kognitif yang digunakan untuk menggambarkan kemampuan dalam mengenali dan menerapkan konsep terkait transaksi serta dalam memahami, menganalisis, mempertimbangkan, mengevaluasi dan menyarankan solusi finansial. Domain proses mencakup: mengidentifikasi informasi finansial, menganalisis informasi dalam konteks finansial, mengevaluasi masalah finansial, serta menerapkan pengetahuan dan pemahaman finansial. Sementara domain konteks mengacu kepada situasi terkait penerapan pengetahuan, keterampilan, dan pemahaman finansial. Domain konteks mencakup pendidikan dan pekerjaan, rumah dan keluarga, individu, serta masyarakat.

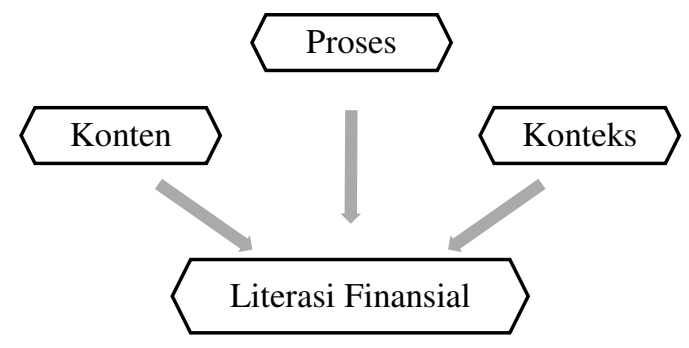

Gambar 2.

Kaitan antar Domain Literasi Finansial

Konten uang dan transaksi mencakup kesadaran tentang ragam bentuk dan tujuan uang serta menangani transaksi moneter sederhana seperti pembayaran harian, pengeluaran, nilai uang, kartu bank, cek, rekening bank, dan mata uang.

Konten perencanaan dan pengelolaan finansial mencakup penge-tahuan dan kemampuan untuk memantau pemasukan dan pengeluaran serta untuk menggunakan pemasukan dan sumber daya lain yang tersedia dalam jangka pendek dan panjang guna meningkatkan kesejahteraan finansial.

Konten risiko dan imbalan adalah bidang utama literasi finansial, yang menggabungkan kemampuan untuk mengidentifikasi cara mengelola, menyeimbangkan, dan mengatasi risiko serta pemahaman tentang potensi keuntungan atau kerugian finansial di berbagai konteks. Terdapat dua jenis risiko yang sangat penting dalam bidang ini. Yang pertama berkaitan dengan kerugian finansial yang tidak dapat 
ditanggung seseorang, seperti yang disebabkan oleh bencana atau biaya berulang. Yang kedua adalah risiko yang melekat pada produk finansial, seperti perjanjian kredit dengan suku bunga variabel, atau produk investasi.

Konten lanskap finansial berkaitan dengan karakter dan fitur dunia finansial, yang mencakup pengetahuan hak dan tanggung jawab konsumen di pasar finansial maupun dalam lingkungan finansial umum, serta implikasi utama dari kontrak finansial. Sumber daya informasi dan peraturan hukm juga merupakan topik yang terkait dengan bidang konten lanskap finansial. Dalam arti luas, lanskap finansial menggabungkan pemahaman tentang konsekuensi dari perubahan kondisi ekonomi dan kebijakan publik, seperti perubahan tingkat suku bunga, inflasi, dan perpajakan.

Proses mengidentifikasi infor-masi finansial digunakan ketika orang mencari dan mengakses sumber informasi finansial, serta mengidentifikasi kaitannya dengan kebutuhan. Informasi ini dapat berbentuk teks cetak seperti kontrak kerja atau digital semisal iklan. Contoh yang mungkin biasa dialami ialah fitur nota dan faktur pembelian serta laporan saldo dalam rekening bank.

Proses menganalisis informasi dalam konteks finansial termasuk menafsirkan, membandingkan, menyintesis, dan mengekstrapolasi informasi yang tersedia. Proses ini melibatkan pengenalan terhadap informasi yang tidak eksplisit, seperti mengidentifikasi asumsi yang mendasari atau implikasi dari masalah tertentu dalam konteks finansial. Contoh paling mudah ialah membandingkan ketentuan yang ditawarkan oleh penyedia layanan jaringan yang berbeda.

Proses mengevaluasi masalah finansial mencakup mengenali atau membangun justifikasi dan penjelasan finansial serta menggunakan penge- tahuan dan pemahaman finansial yang diterapkan dalam konteks tertentu. Proses ini melibatkan penjelasan, penilaian, dan generalisasi informasi yang tersedia. Karena itu, dalam proses ini diperlukan pemikiran kritis dalam memahami dan membentuk pandangan tentang masalah finansial.

Proses menerapkan pengetahuan dan pemahaman finansial berfokus kepada mengambil tindakan yang efektif dalam pengelolaan finansial berdasarkan pemahaman produk, konteks, dan konsep terkair. Proses ini tercermin dalam kegiatan yang melibatkan perhitungan dan penyelesaian masalah, yang seringkali harus mempertimbangkan kondisi tertentu. Contoh dari proses ini adalah menghitung besaran bunga kredit pembelian barang.

Konteks pendidikan dan pekerjaan termasuk memahami slip pembayaran, merencanakan menabung untuk pendidikan tinggi, menyelidiki manfaat dan risiko ikutserta dalam skema tabungan di lembaga pendidikan atau tempat kerja.

Konteks rumah dan keluarga termasuk masalah finansial yang berkaitan dengan biaya yang diperlukan untuk menjalankan rumah tangga seperti membeli perabotan rumah tangga atau belanjaan keluarga, menyimpan catatan pengeluaran keluarga, serta membuat rencana penganggaran dan prioritas pengeluaran.

Konteks individual mencakup masalah seperti membuka rekening bank, membeli barang konsumsi pribadi, mengeluarkan uang untuk kegiatan pribadi, maupun urusan dengan layanan finansial yang terkait, seperti kredit dan asuransi.

Konteks masyarakat mencakup hal-hal seperti hak dan tanggung jawab konsumen, pajak, dan retribusi daerah, kepentingan bisnis, serta daya beli konsumen. Pilihan finansial seperti menyumbang ke organisasi nirlaba dan 
lembaha amal juga dapat dimasukkan ke dalam konteks ini.

Berdasarkan ulasan yang disajikan, dapat dikatakan bahwa bentuk paduan fiqh mu'ämalät dan literasi finansial ialah fiqh mu'ämalāt muncul untuk memperkaya perspektif literasi finansial, sementara perspektif literasi finansial dipakai agar pengamalan fiqh mu'ämalät bisa tepat guna. Paduan keduanya secara langsung dapat digunakan untuk mewujudkan maqōṣid syarīàt (beberapa tujuan syari'at), terutama dalam aspek menjaga kekayaan (yahfaz al-māt), supaya dapat menghilangkan bahaya (yuzāl aldoror) yang dialami ketika terlibat transaksi (al-Ghozālī, 1993: 174; alSuyūṭī, 1990: 83).

Tahap design dimulai dengan menyusun instrumen penilaian pembelajaran. Pilihan ini diambil karena hasil belajar berupa literasi finansial sudah ditentukan, sehingga lebih tepat kalau instrumen penilaian pembelajaran disusun lebih dahulu. Dengan acuan penilaian tersebut, kemudian ditentukan proses pembelajaran yang harus dialami oleh pelajar. Agar tujuan proses tersebut selaras dengan hasil yang diharapkan, kami turut menyusun lembar kerja siswa (LKS). LKS juga berguna untuk memudahkan pelaksanaan sekaligus mengevaluasi proses pembelajaran. Langkah terakhir tahap design ini ialah menyusun program pembelajaran, yang dibuat berdasarkan hasil yang diharapkan dan proses yang memungkinkan untuk dilaksanakan.

Instrumen penilaian pembelajaran yang dirancang berjumlah 12 butir soal yang terbagi ke dalam 4 kelompok soal. Instrumen tersebut disusun dalam tes objektif beralasan untuk menghindari kesubjektifan dalam memeriksa jawaban, mengurangi kesulitan dalam memberikan skor, serta meminimalisir waktu pengoreksian instrumen. Selain itu, dalam urusan finansial, biasanya seseorang sudah memiliki beberapa pilihan dalam membuat keputusan. Keberadaan pilihan jawaban dipakai untuk membiasakan pelajar untuk membuat keputusan berdasarkan beberapa pilihan. Penambahan alasan dipakai untuk mengarahkan pelajar kepada jawaban yang diharapkan serta mengurangi peluang menjawab secara spekulatif. Sehingga keberadaan alasan dipakai sebagai faktor tebakan (koefisien penilaian). Dengan demikian, penilaian setiap butir soal dilakukan menggunakan persamaan berikut:

$$
\begin{aligned}
& N_{i}=S_{i} \times F_{i} \quad \text { (Persamaan 1.) } \\
& \text { keterangan: } \\
& N_{i} \quad=\text { nilai setiap butir soal (nilai } \\
& 0-2) \quad=\text { skor setiap butir pilihan } \\
& S_{i} \quad=\text { skor faktor tebakan setiap } \\
& \text { jawaban (nilai } 0-1) \\
& \left.F_{i} \quad \text { and soal (nilai } 0-2\right) \\
& \text { butir }
\end{aligned}
$$

\begin{tabular}{|c|c|}
\hline Skor & Bentuk Uraian \\
\hline 2 & $\begin{array}{c}\text { Alasan terkait serta mendukung jawaban } \\
\text { yang dipilih }\end{array}$ \\
\hline 1 & $\begin{array}{l}\text { Alasan terkait, tapi tidak mendukung } \\
\text { jawaban yang dipilih }\end{array}$ \\
\hline 0 & $\begin{array}{l}\text { Alasan tidak terkait dengan jawaban yang } \\
\text { dipilih }\end{array}$ \\
\hline 0 & Alasan tidak disampaikan \\
\hline
\end{tabular}

Tabel 3. Klasifikasi Faktor Tebakan

Persamaan 1 dan tabel 3 menunjukkan bahwa setiap pilihan jawaban dan alasan dapat memiliki skor sendiri. Skor faktor tebakan dapat maksimal selama alasan terkait serta mendukung jawaban yang dipilih. Namun, karena jawaban yang dipilih salah, nilai yang diperoleh dapat bernilai 0 akibat mengalami operasi perkalian. Begitu pula sebaliknya. 


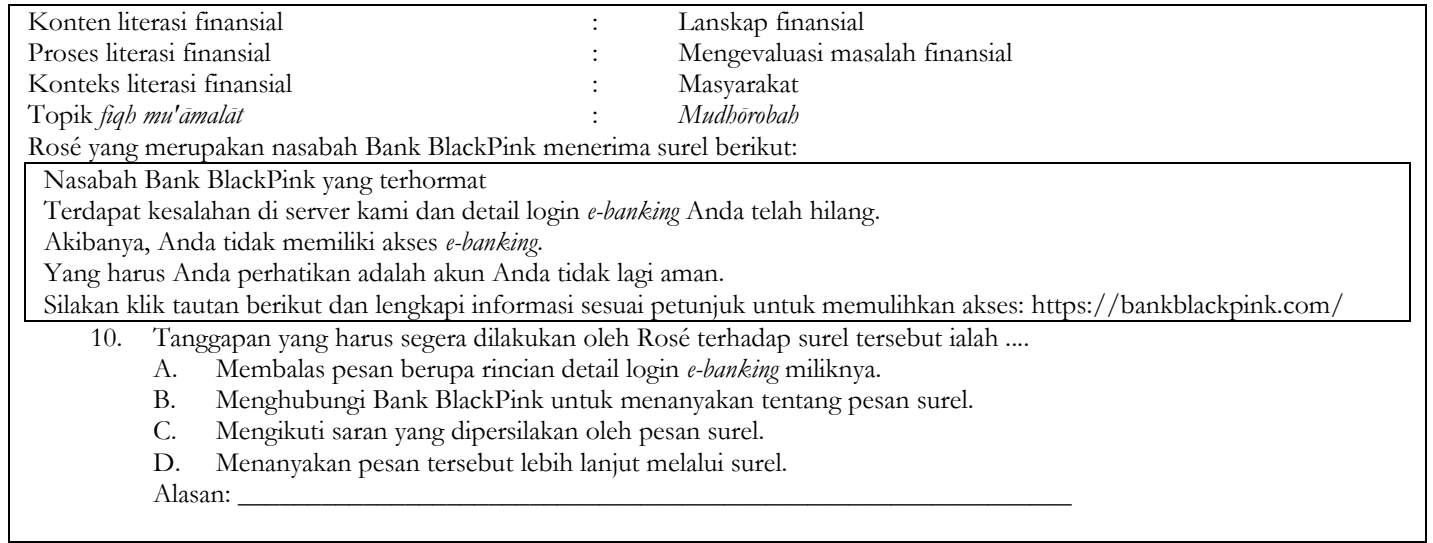

Gambar 3. Contoh Butir Soal yang Disusun

Sampel soal yang disajikan melalui gambar 1 terkait dengan konten lanskap finansial dalam konteks masyarakat. Hal ini karena internet banking adalah bagian dari transaksi finansial yang memiliki banyak fitur dengan ruang lingkup lebih luas daripada urusan pribadi. Proses terkait soal tersebut ialah mengevaluasi masalah finansial karena siswa harus mengevaluasi pilihan yang disajikan dan mengenali saran yang lebih menguntungkan atau tidak lebih merugikan untuk diambil. Topik fiqh mu'amalät dalam sampel soal tersebut ialah transaksi model mudhörobah. Transaksi ini bersifat lebih umum daripada wadi'ah, walau untuk remaja terdapat program perbankan yang sekilas tampak menerapkan 'aqd wadi'ah seiring ketiadaan biaya administrasi dan bunga bank, seperti BNI Taplus Anak dari BNI.

Melalui soal tersebut, pelajar dituntut untuk cakap dalam menganalisis produk finansial sebagai bahan mengambilkeputusan ketika menghadapi masalah terkait, seperti penipuan atas nama bank yang disajikan melalui soal. Dari sisi pembelajaran, kegiatan yang menunjang ke arah tersebut ialah kajian tentang beberapa aqd terkait, seperti mudhörobah dan wadi'ah serta posisi bunga bank, biaya administrasi, serta pajak dalam ruang lingkup ribā.

Kegiatan tersebut dapat diwujudkan dengan multi-model yang selama ini telah mengakar diterapkan di pondok pesantren, yakni: bandongan (ceramah atau lecture) untuk memberi uraian secara utuh terkait dasar fiqh mu'amalät tertentu; sorogan agar dapat melatih pelajar dalam mengomunikasikan hasil kajian terhadap topik tersebut, serta musyāwaroh (bahts almasāil, problem-based learning, atau casebased learning) guna membiasakan pelajar terampil dalam mengambil keputusan ketika menghadapi masalah atau kasus tertentu.

Tabel 4. Matriks Fiqh Múamalät dan Literasi Finansial untuk Instrumen Penilaian

\begin{tabular}{|c|c|c|c|c|}
\hline \multirow{2}{*}{$\begin{array}{l}\text { No. } \\
\text { Soal }\end{array}$} & \multicolumn{3}{|c|}{ Literasi Finansial } & \multirow{2}{*}{$\begin{array}{c}\text { Fiqh } \\
\text { Mu'āmalāt }\end{array}$} \\
\hline & Konten & Proses & Konteks & \\
\hline 1 & Uang dan transaksi & $\begin{array}{l}\text { Mengidentifikasi informasi } \\
\text { finansial }\end{array}$ & Individu & Istișnā' \\
\hline
\end{tabular}




\begin{tabular}{|c|c|c|c|c|}
\hline 2 & Uang dan transaksi & $\begin{array}{l}\text { Mengidentifikasi informasi } \\
\text { finansial }\end{array}$ & Individu & Istișnā' \\
\hline 3 & Uang dan transaksi & $\begin{array}{l}\text { Mengidentifikasi informasi } \\
\text { finansial }\end{array}$ & Individu & Istișnā' \\
\hline 4 & Risiko dan imbalan & $\begin{array}{c}\text { Menganalisis informasi dalam } \\
\text { konteks finansial }\end{array}$ & $\begin{array}{l}\text { Pendidikan dan } \\
\text { pekerjaan }\end{array}$ & Ijärob \\
\hline 5 & Risiko dan imbalan & $\begin{array}{c}\text { Menganalisis informasi dalam } \\
\text { konteks finansial }\end{array}$ & $\begin{array}{l}\text { Pendidikan dan } \\
\text { pekerjaan }\end{array}$ & Musyārokah \\
\hline 6 & Risiko dan imbalan & $\begin{array}{c}\text { Menganalisis informasi dalam } \\
\text { konteks finansial }\end{array}$ & $\begin{array}{l}\text { Pendidikan dan } \\
\text { pekerjaan }\end{array}$ & Musyärokah \\
\hline 7 & $\begin{array}{c}\text { Perencanaan dan } \\
\text { pengelolaan finansial }\end{array}$ & $\begin{array}{l}\text { Menerapkan pengetahuan dan } \\
\text { pemahaman finansial }\end{array}$ & $\begin{array}{l}\text { Rumah dan } \\
\text { keluarga }\end{array}$ & Ijäroh \\
\hline 8 & $\begin{array}{c}\text { Perencanaan dan } \\
\text { pengelolaan finansial }\end{array}$ & $\begin{array}{l}\text { Menerapkan pengetahuan dan } \\
\text { pemahaman finansial }\end{array}$ & $\begin{array}{l}\text { Rumah dan } \\
\text { keluarga }\end{array}$ & Murōbạ̣ab \\
\hline 9 & $\begin{array}{l}\text { Perencanaan dan } \\
\text { pengelolaan finansial }\end{array}$ & $\begin{array}{l}\text { Menerapkan pengetahuan dan } \\
\text { pemahaman finansial }\end{array}$ & $\begin{array}{l}\text { Rumah dan } \\
\text { keluarga }\end{array}$ & Murōbaḥah \\
\hline 10 & Lanskap finansial & $\begin{array}{l}\text { Mengevaluasi masalah } \\
\text { finansial }\end{array}$ & Masyarakat & Mudhōrobah \\
\hline 11 & Lanskap finansial & $\begin{array}{l}\text { Mengevaluasi masalah } \\
\text { finansial }\end{array}$ & Masyarakat & Mudhōrobah \\
\hline 12 & Lanskap finansial & $\begin{array}{l}\text { Mengevaluasi masalah } \\
\text { finansial }\end{array}$ & Masyarakat & Mudhōrobah \\
\hline
\end{tabular}

Dalam pelaksanaan proses pembelajaran, pelajar diberi LKS yang memuat langkah sesuai dengan indikator yang dibekalkan. Dengan demikian LKS bisa menuntun pelajar untuk mencapai hasil belajar yang telah ditetapkan.

Secara rinci, LKS diberikan untuk meminta pelajar mengembangkan ulasan yang disampaikan melalui bandongan sebagai bahan menyiapkan sorogan (individual) serta musyāwaroh (kelompok). Secara urut, LKS disusun berdasarkan alur penuturan al-Ghōyah wa al-Taqrïb. Alur ini dipilih agar pembelajaran sorogan kitab kuning serta musyāwaroh nahwiyyah dan fiqhiyyah yang telah dilakukan tidak perlu mengalami perubahan. Karena uraian yang disampaikan dalam al-Ghōyah wa al-Taqrib cukup singkat, melalui LKS pelajar juga diarahkan agar mengelaborasi lebih lanjut melalui referensi lain, seperti Qurrotu al'Ayn, Fath al-Qorìb al-Mujīb, Kifäyat al-Akbyarr, Fath al-Mu'in, Nihāyatu al-Zayn, Hāsyiyat alBājūrì 'alā Ibn Qōsim al-Ghō̌̀̃, I'ànatu alTölibin, dan al-Fiqh al-Islàmi wa Adillatubu.

Rancangan instrumen penilaian pembelajaran dan LKS tersebut kemudian dianalisis keabsahan dan keandalannya di tahap develop sebagai bahan menyusun program pembelajaran. Keabsahan instrumen penilaian pembelajaran dan LKS ditentukan berdasarkan validasi pakar (Fraenkel \& Wallen, 2009: 148). Validasi dilakukan terhadap keselarasan instrumen penilaian pembelajaran dan LKS dengan program yang dikembangkan, kesesuaian indikator dengan instrumen penilaian pembelajaran dan LKS, ketepatan jawaban dengan pertanyaan dalam instrumen penilaian pembelajaran dan LKS, serta kecocokan tingkat pendidikan dengan instrumen penilaian pembelajaran dan LKS. Kriteria untuk pakar tersebut berupa akademisi dengan bidang kepakaran fiqh mu'ämalät (Pakar1), bidang finansial (Pakar-2) dan pembelajaran pendidikan menengah (Pakar-3) serta praktisi profesional bidang finansial (Pakar-4) dan terkait bahasa (Pakar-5).

Instrumen yang dipakai untuk mengukur keabsahan ialah lembar validasi butir pernyataan. Lembar tersebut diberi skor menggunakan 
skala Likert. Kelebihan skala Likert sebagai pengukur tanggapan secara verbal maupun numerik terhadap kuesioner, dapat memberi nilai kuantitatif dalam rentang spektrum yang panjang (Likert, 1932: 7). Sedangkan kekurangannya berupa sikap terdistribusi secara normal ke dalam lima kategori persetujuan (Likert, 1932: 42). Memperhatikan kelebihan dan kekurangan, skala Likert dipilih karena hasilnya dapat diolah baik secara statistik maupun desktriptif. Letak kekurangan berupa pembagian tingkat persetujuan ke dalam lima kategori diatasi dengan menggunakan tujuh tingkat secara numerik.

Nilai keabsahan (validity) ditentukan berdasarkan penilaian pakar terhadap ketepatan antara rancangan dan indikator, pertanyaan dan jawaban, serta soal dengan subjek sasaran (Fraenkel \& Wallen, 2009: 148). Hasil validasi berupa penilaian numerik skala 7 terhadap setiap butir pernyataan yang diolah menggunakan persamaan 1 (Setiawan, 2019: 227):

$$
\begin{aligned}
& P(s)=\frac{s}{N} \times 100 \% \\
& \text { (Persamaan 2.) } \\
& \text { keterangan: } \\
& \begin{array}{ll}
P(s) \quad & \text { Nilai setiap butir } \\
& \text { pernyataan } \\
& =\text { skor setiap butir } \\
N & \text { pernyataan } \\
N & =\text { jumlah butir pernyataan }
\end{array}
\end{aligned}
$$

kemudian ditafsirkan berdasarkan tabel berikut, yakni dapat digunakan kalau memenuhi kriteria 'sangat layak' atau 'cukup layak' (Setiawan, 2019: $5)$.

Tabel 5. Penafsiran Penilaian Keabsahan Instrumen

\begin{tabular}{ccc}
\hline No. & $\begin{array}{c}\text { Rentang Rerata } \\
\text { Penilaian Numerik } \\
\text { Pakar (\%) }\end{array}$ & $\begin{array}{c}\text { Kriteria } \\
\text { Kelayakan }\end{array}$ \\
\hline 1 & $7,001 \leq \% \leq 10,000$ & Sangat layak \\
\hline 2 & $4,001 \leq \% \leq 7,000$ & Cukup layak \\
\hline 3 & $0,000 \leq \% \leq 4,000$ & Tidak layak \\
\hline \multicolumn{4}{c}{ (Setiawan, 2019: 5) }
\end{tabular}

Sementara untuk mengukur keandalan (reliability), dipakai rancangan yang telah diperbaiki berdasarkan lembar validasi. Keandalan instrumen penilaian pembelajaran dan lembar kerja siswa ditentukan berdasarkan konsistensi internal (internal consistency). Konsistensi internal biasanya diukur dengan alfa Cronbach (a), salah satu cara statistik untuk mengetahui korelasi berpasangan antar butir pertanyaan atau pernyataan, yang dapat dihitung menggunakan persamaan Kuder-Richardson Approaches (KR20) (persamaan 2) (Cronbach, 1951: 299):

$$
\alpha=\frac{n}{n-1}\left(1-\frac{\sum_{i} V_{i}}{V_{t}}\right)
$$

(Persamaan 3.)

keterangan:

$$
\begin{aligned}
& \alpha \quad=\text { koefisien alfa } \\
& n \quad=\quad \text { jumlah butir } \\
& \text { pernyataan } \\
& V i \quad=\text { simpangan baku setiap } \\
& \text { butir } \\
& V t \quad=\text { simpangan baku semua }
\end{aligned}
$$

Persamaan 3 mengungkap bahwa alfa Cronbach adalah fungsi dari jumlah butir pernyataan serta simpangan baku setiap butir dan keseluruhan. Ini menunjukkkan bahwa nilai alfa Cronbach dapat meningkat ketika interelasi antar butir meningkat. Karena itu, dapat dipakai untuk memperkirakan konsistensi internal sebagai nilai numerik keandalan skor instrumen penilaian pembelajaran dan lembar kerja siswa.

Persamaan 3 juga bermakna bahwa dibutuhkan uji coba. Hasil ujicoba dapat ditafsirkan berdasarkan tabel 6, yakni dapat dipakai kalau nilai koefisien alfa lebih besar dari 0,70 (Fraenkel \& Wallen, 2009: 157-8). Dalam melaksanakan ujicoba tersebut kami memilih partisipan sebanyak 50 pelajar. Keseluruhan partisipan ujicoba dipilih menggunakan teknik convenience sampling untuk menghemat tenaga karena kami terlibat sebagai pemandu pembelajaran aktual 
partisipan (Fraenkel \& Wallen, 2009: 101).

Tabel 6. Penafsiran Penilaian Keandalan Instrumen

\begin{tabular}{ccc}
\hline No. & $\begin{array}{c}\text { Nilai Alfa } \\
\text { Cronbach }\end{array}$ & Kategori Keandalan \\
\hline 1 & $\alpha \leq 0,9$ & Luar biasa \\
\hline 2 & $0,8 \leq \alpha<0,9$ & Baik \\
\hline 3 & $0,7 \leq \alpha<0,8$ & Dapat diterima \\
\hline 4 & $0,6 \leq \alpha<0,7$ & Dipertanyakan \\
\hline 5 & $0,5 \leq \alpha<0,6$ & Rendah \\
\hline 6 & $\alpha<0,5$ & Tidak dapat diterima \\
\hline \multicolumn{2}{c}{ (disusun berdasarkan uraian Morera \& Stokes, }
\end{tabular}

2016)

Hasil dari tahap develop berupa validasi pakar dan ujicoba digunakan sebagai bahan penyusunan program pembelajaran dalam bentuk silabus. Berdasarkan pertimbangan prioritas pembahasan, tingkat penalaran, serta struktur kurikulum, sasaran program pembelajaran ialah pelajar yang sudah mengalami pembelajaran fiqh íbādāt. Dalam bentuk aktual, sasaran tersebut tampak secara langsung mengarah kepada santri yang memasuki tahun ketiga di pondok pesantren dan/atau siswa kelas IX. Namun, tidak menutup kemungkinan santri atau siswa di luar himpunan tersebut masuk ke dalam sasaran program pembelajaran. Yang jelas, program pembelajaran memerlukan rentang waktu paling sedikit satu semester.

Kaitan antara silabus dengan instrumen penilaian pembelajaran dan LKS mewujud dalam bentuk rencana pelaksanaan pembelajaran (RPP, lesson plan). Selanjutnya instrumen penilaian pembelajaran, LKS, dan RPP dapat disebarkan secara luas dalam satu paket perangkat pembelajaran atau terpisah. Satu paket yang dimaksud ialah digunakan seutuhnya berdasarkan kerja kami. Sedangkan terpisah berarti hanya diambil seperlunya, seperti instrumen penilaian pembelajaran untuk mengukur profil literasi finansial pelajar. Keter- batasan tenaga membuat kami tidak melakukan penyebaran secara luas yang merupakan tahap terakhir berupa disseminate.

Tabel 7. Hasil Validasi Pakar terhadap Instrumen Penilaian Pembelajaran

\begin{tabular}{|c|c|c|c|c|c|c|c|}
\hline \multirow{2}{*}{$\begin{array}{l}\text { No } \\
\text { so } \\
\text { al }\end{array}$} & \multicolumn{5}{|c|}{$\begin{array}{c}\text { Skor Setiap } \\
\text { Pakar }\end{array}$} & \multirow{2}{*}{$\begin{array}{c}\text { Skor } \\
\text { Keselu } \\
\text {-ruhan }\end{array}$} & \multirow{2}{*}{$\begin{array}{l}\text { Kriteria } \\
\text { Kelayakan }\end{array}$} \\
\hline & 1 & 2 & 3 & 4 & 5 & & \\
\hline 1 & 7 & 6 & 5 & 3 & 3 & 69 & $\begin{array}{l}\text { Cukup } \\
\text { Layak }\end{array}$ \\
\hline 2 & 5 & 6 & 6 & 7 & 4 & 80 & Sangat Layak \\
\hline 3 & 5 & 7 & 6 & 3 & 3 & 69 & $\begin{array}{l}\text { Cukup } \\
\text { Layak }\end{array}$ \\
\hline 4 & 5 & 6 & 6 & 5 & 3 & 71 & Sangat Layak \\
\hline 5 & 5 & 3 & 7 & 2 & 3 & 57 & $\begin{array}{c}\text { Cukup } \\
\text { Layak }\end{array}$ \\
\hline 6 & 4 & 6 & 7 & 5 & 5 & 77 & Sangat Layak \\
\hline 7 & 5 & 5 & 7 & 7 & 4 & 80 & Sangat Layak \\
\hline 8 & 6 & 6 & 4 & 4 & 5 & 71 & Sangat Layak \\
\hline 9 & 6 & 6 & 4 & 3 & 7 & 74 & Sangat Layak \\
\hline 10 & 6 & 5 & 6 & 3 & 4 & 69 & $\begin{array}{l}\text { Cukup } \\
\text { Layak }\end{array}$ \\
\hline $\begin{array}{l}1 \\
1\end{array}$ & 6 & 5 & 6 & 3 & 3 & 66 & $\begin{array}{l}\text { Cukup } \\
\text { Layak }\end{array}$ \\
\hline 12 & 6 & 6 & 6 & 3 & 5 & 74 & Sangat Layak \\
\hline
\end{tabular}

\section{KESIMPULAN}

Dapat dikatakan bahwa fiqh mu'āmalāt dan literasi finansial dapat dipadukan. Bentuk paduan keduanya ialah figh mu'āmalāt muncul untuk memperkaya perspektif literasi finansial, sementara perspektif literasi finansial dipakai agar pengamalan fiqh mu'āmalāt bisa tepat guna. Paduan keduanya secara langsung dapat digunakan untuk mewujudkan maqōṣid syarīāt (beberapa tujuan syarì̄āt), terutama dalam aspek menjaga kekayaan (yahfaz al-māt), supaya dapat menghilangkan bahaya (yuzāl al-ḍoror) yang dialami ketika terlibat transaksi. Karena itu, dapat disusun program pembelajaran yang memadukan fiqh mu'āmalāt dan literasi finansial. 
Berdasarkan pertimbangan prioritas pembahasan, tingkat penalaran, serta struktur kurikulum, sasaran program pembelajaran ialah pelajar yang sudah mengalami pembelajaran fiqh 'ibādāt. Program pembelajaran tersebut memerlukan rentang waktu paling sedikit satu semester untuk mempelajari ragam transaksi dalam kategori penjualan, penyimpanan, peminjaman, penyewaan, penjaminan, pemberian, dan penemuan.

Seluruh ragam transaksi tersebut dipelajari dari sisi fiqh mu'āmalāt mencakup prinsip dasar, unsur hukm, dan jenis transaksi, serta dari sisi literasi finansial meliputi konten, proses, dan konteks. Dalam pelaksanaan proses pembelajaran, pelajar diberi LKS yang memuat langkah sesuai dengan indikator yang dibekalkan, guna menuntun pelajar untuk mengelaborasi lebih lanjut supaya bisa mencapai hasil belajar yang telah ditetapkan. Hasil belajar diukur menggunakan instrumen penilaian pembelajaran yang disusun berdasarkan indikator literasi finansial dengan diperkaya topik fiqh mu'āmalāt.

Kami menganggap bahwa kerja yang kami lakukan ini masih perlu dilanjutkan. Apalagi Keterbatasan tenaga membuat kami tidak melakukan penyebaran secara luas (disseminate) yang merupakan tahap terakhir dalam metode riset model fourd. Karena itu, diharapkan penyusunan program ini tidak dianggap final, sehingga perlu dilakukan perbaikan berlanjut.

\section{REFERENSI}

al-Aṣfihāān̄, Aḥmad ibn al-Ḥusayn. (2019). al-Ghöyah wa al-taqrï. Kudus: Pondok Pesantren AthThullab.

al-Bantānī, Muḥammad ibn 'Umar. (2008). Nihayatu al-zayn. Beirut: Dār al-Fikr. URL: https://almaktaba.org/book/6146
al-Dimyāț̣ī, Abū Bakr 'Utsman ibn Muhammad. (1997). I'ānatu altoolibin. Beirut: Dār al-Fikr. URL: https://almaktaba.org/book/33983

al-Ghozālī, Abū Ḥāmid Muḥammad ibn Muḥammad. (1993). Al-Mustașfā min ilm al-uṣūl. Beirut: Dār Kutub al-Ilmiyyah. URL: https://almaktaba.org/book/5459

al-Ghozī, Muḥammad ibn Qāsim. (2005). Fath al-qorib al-mujizb. Beirut: Beirut: Dār ibn Hazm. URL: $\quad$ https://almaktaba.org/book/33949

al-Ḥuṣnī, Abū Bakr ibn Muhammad. (1994). Kifāyat al-akbyār. Damaskus: Dār al-Khoir. URL: https://al-

maktaba.org/book/6140

al-Malībārī, Aḥmad ibn 'Abd al-Azīz. (2005). Fath al-mu'in bi syarh qurrotu al-ayn bi mubimmāt al-din. Beirut: Beirut: Dār ibn Hazm. URL: https://almaktaba.org/book/11327

al-Malībārī, Aḥmad ibn 'Abd al-Azīz. (2019). Qurrotu al-ayn bi mubimmàt al-dìn. Kudus: Pondok Pesantren Ath-Thullab.

al-Suyūṭị, 'Abd al-Roḥmān ibn Abī Bakr. (1990). al-Asybah wa al-nazóoir. Beirut: Dār al-Kutub al'Ilmiyyah. URL: $\quad$ https://almaktaba.org/book/21719

al-Zuḥaylī, Wahbah ibn al-Muṣṭōāā. (1989). al-Figh al-islämi wa adillatubu. Damaskus: Dār al-Fikr. URL: https://almaktaba.org/book/33954

Cronbach, Lee J. (1951, September). Coefficient alpha and the internal structure of tests. Psychometrika, 16: 297-334. URL: http://psych.colorado.edu/ carey /courses/psyc5112/readings/alph a_cronbach.pdf 
Fraenkel, Jack R. \& Wallen, Norman E.(2009). How to design and evaluate research in education (7the ed.). New York: McGraw-Hill Companies. URL:

https://archive.org/details/metho dology-alobatnic-libraries

Likert, Rensis. 1932. A technique for the measurement of attitudes. Archives of Psychology, $140: 1-55$. URL: https://legacy.voteview.com/pdf/ Likert_1932.pdf

Madjid, Nurcholish. (1997). Bilik-bilik pesantren: sebuab potret perjalanan. Jakarta Selatan: Paramadina. URL: https://archive.org/details/nmbb $\mathrm{p}$

Mahmada, Nong Darol. (2001, 30 Juli 05 Agustus). Membangun fikih yang pro-perempuan. Majalah TEMPO, 22 (30). URL: https://majalah.tempo.co/read/8 $1720 /$ membangun-fikih-yang-properempuan

Morera, Osvaldo F. \& Stokes, Sonya M. (2016, 17 Februari). Coefficient $\alpha$ as a measure of test score reliability: review of 3 popular misconceptions. American Journal of Public Health, 106(3): 458-461. DOI:

https://dx.doi.org/10.2105\%2FAJ PH.2015.302993

Octavia, Lanny. (2014, 01 Januari). Pendidikan karakter berbasis tradisi pesantren. Jakarta Selatan: Renebook. URL: https://play.google.com/store/bo oks/details/Pendidikan_Karakter_ Berbasis_Tradisi_Pesantren?id $=\mathrm{h}$ EdODAAAQBAJ\&hl=bs

OECD. (2005, Juli). Recommendation on principles and good practices for financial education and awareness. Paris: Directorate for Financial and Enterprise Affairs. URL: http://www.oecd.org/finance/fin ancial-education/35108560.pdf
OECD. (2015, 16 November). National strategies for financial education: oecd/infe policy bandbook. Paris: OECD Publishing. URL: https://www.oecd.org/daf/fin/fi nancial-education/nationalstrategies-for-financial-educationpolicy-handbook.htm

OECD. (2019, 26 April). Pisa 2018 assessment and analytical framework. Paris: OECD Publishing. DOI: https://dx.doi.org/10.1787/b25ef ab8-en

OJK. (2017, 20 Desember). Strategi nasional literasi finansial indonesia (revisit 2017). Jakarta Pusat: Otoritas Jasa Finansial (OJK). URL: https://www.ojk.go.id/id/beritadan-

kegiatan/publikasi/Pages/StrategiNasional-Literasi-FinansialIndonesia-(Revisit-2017)-.aspx

Setiawan, Adib Rifqi. (2019, 14 Oktober). Penyusunan program pembelajaran biologi berorientasi literasi saintifik. Seminar Nasional Sains \& Entrepreneurship VI, 1(1). URL:

http://conference.upgris.ac.id/ind ex.php/snse/article/view/255

Setneg. (2013, 13 November). Sambutan presiden $r i$ pd strategi nasional literasi finansial, tgl 19 nov. 2013, di joc. Jakarta Pusat: Kementerian Sekretariat Negara Republik Indonesia. URL: https://www.setneg.go.id/baca/in dex/sambutan_presiden_ri_pd_str ategi_nasional_literasi_finansial_tg 1_19_nov_2013_di_jcc

Thiagarajan, Sivasailam, dkk. (1974). Instructional development for training teachers of exceptional children: a sourcebook. Washington, D. C.: National Center for Improvement of Educational Systems (DHEW/OE). URL: 
Model Teams Games Tournament: Suatu Analisis Hasil Implementasi dalam Pembelajaran Pendidikan Agama Islam

https:// files.eric.ed.gov/fulltext/E

D090725.pdf

Umar, Nasaruddin. (2014, 24 Maret).

Ketika fikih membela perempuan.

Jakarta Pusat: Elex Media

Komputindo. URL:

https://books.google.co.id/books

/about/Ketika_Fikih_Membela_P

erempuan.html?id $=$ rYhKDwAAQ

BAJ\&redir_esc $=y$

TARBAWY: Indonesian Journal of Islamic Education - Vol. 6 No. 2 (2019) | 192 